\title{
The Unpolitical Petrarch: Justifying the Life of Literary Retirement
}

\section{Citation}

Hankins, James. 2017. The Unpolitical Petrarch: Justifying the Life of Literary Retirement. In Et Amicorum: Essays on Renaissance Humanism and Philosophy: In Honour of Jill Kraye, edited by Anthony Ossa-Richardson and Margaret Meserve, 5-32. Leiden: Brill.

\section{Permanent link}

http://nrs.harvard.edu/urn-3:HUL.InstRepos:41275730

\section{Terms of Use}

This article was downloaded from Harvard University's DASH repository, WARNING: This file should NOT have been available for downloading from Harvard University's DASH repository.

\section{Share Your Story}

The Harvard community has made this article openly available.

Please share how this access benefits you. Submit a story.

\section{Accessibility}




\section{Et Amicorum: Essays on Renaissance Humanism and Philosophy \\ in Honour of Jill Kraye}

Edited by

Anthony Ossa-Richardson

Margaret Meserve

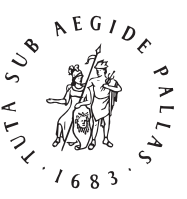

B R I L L

LEIDEN | BOSTON

For use by the Author only | (C) 2018 Koninklijke Brill NV 


\section{Contents}

Foreword XI

List of Illustrations XII

1 Jill Kraye: The History of Philosophy as a Humanistic Discipline 1 Anthony Grafton

\section{PART 1}

Humanism and its Reception

2 The Unpolitical Petrarch:Justifying the Life of Literary Retirement 7 James Hankins

3 Lauro Quirini and His Greek Manuscripts: Some Notes on His Culture 33

John Monfasani

4 Translating Aristotle in Fifteenth-Century Italy: George of Trebizond and Leonardo Bruni 47

J. Cornelia Linde

5 Illuminated Copies of Plutarchus, Vitae illustrium virorum, Venice:

Nicolaus Jenson, 1478: New Attributions, New Patrons 69

Lilian Armstrong

6 A Roman Monster in the Humanist Imagination 118

Margaret Meserve

7 Tau's Revenge 144

Anthony Ossa-Richardson

8 A Knowing Likeness: Artists and Letterati at the Farnese Court in mid Sixteenth-Century Rome 159

Dorigen Caldwell

9 Greek Antiquities and Greek Histories in the Late Renaissance 177 William Stenhouse 
10 Against 'Humanism': Pico's Job Description 198

Brian Copenhaver

PART 2

Renaissance Philosophy and its Antecedents

11 Acquiring Wings: Augustine's Recurrent Tensions on Creation and the Body 245

Alessandro Scafi

12 The Florilegium Angelicum and 'Seneca', De moribus 262 Michael Reeve

13 Defining Philosophy in Fifteenth-Century Humanism: Four Case Studies 281

David A. Lines

14 Marsilio Ficino on Power, on Wisdom, and on Moses 298 Michael J. B. Allen

15 'If you Don't Feel Pain, you Must Have Lost your Mind': The Early Modern Fortunes of a Hippocratic Aphorism 313

Guido Giglioni

16 Life in Prison: Cardano, Tasso and Campanella 338 Germana Ernst

17 Five Versions of Ramus's Geometry 355 Robert Goulding

18 Justus Lipsius as Historian of Philosophy: The Reception of the Manuductio ad stoicam philosophiam (1604) in the History of Philosophy 388 Jan Papy

19 Can History be Rational? 424 Stefan Bauer 
$20 \quad$ A Crayon for Jill 435

Daniel Andersson

The Publications of Jill Kraye, 1979-2017 439

Martin Davies

Index 449

For use by the Author only | (C) 2018 Koninklijke Brill NV 


\title{
The Unpolitical Petrarch: Justifying the Life of Literary Retirement
}

\author{
James Hankins
}

Francesco Petrarch's involvements in the politics of Trecento Italy have often been the subject of criticism by later readers of his works - in effect, by that same posterity whose good opinion he so eagerly sought, and not just in the famous letter To Posterity. Indeed almost all of Petrarch's literary interventions in the political life of his times come interlaced with pre-emptive apologias for his own stances. Petrarch knew that what he did and what he wrote would draw criticism, or was already drawing criticism. And his works certainly offer to hostile eyes what military tacticians would call a 'target-rich environment'. For there are many political Petrarchs: in approximate chronological order, there is Petrarch the Italian patriot, calling for the common defense of Italy against foreign powers, including the Holy Roman Empire; there is Petrarch the admirer of Robert of Naples' enlightened monarchy; Petrarch the propagandist for Cola di Rienzo's popular revolt against Rome's baronial families; Petrarch the chastened critic of Cola's excesses; Petrarch the bitter opponent of the Avignon papacy; Petrarch the counselor and sometime representative of assorted North Italian signori; and the Petrarch who late in life urged Holy Roman Emperor Charles IV to invade and conquer Italy. ${ }^{1}$ Since all of Petrarch's

1 For modern literature on Petrarch's political thought and action see Wilhelm Kölmel, 'Petrarca und das Reich: Zum historisch-politischen Aspekt der studia humanitatis', Historisches Jahrbuch 90 (1970), 1-30; Giovanni Santinelli, 'Il pensiero politico e religioso del Petrarca', Studia patavina, 21 (1974), 586-601; William Melczer, 'Cola di Rienzo and Petrarch's Political Solitude', Explorations in Renaissance Culture 2 (1975), 1-13; Raoul Manselli, 'Petrarca nella politica delle Signorie padane alla metà del Trecento', Civiltà veneziana, Saggi, vol. 21: Petrarca, Venezia e il Veneto (Florence, 1976), 9-22; Aldo S. Bernardo, 'Petrarch on the Education of a Prince: Familiares 12.2', Medievalia 6 (1980), 135-50; Evelyne Luciani, 'Théodore, idéal du prince chrétien dans la correspondance de Pétrarque. Sources augustiniennes', Revue des études augustiniennes 31 (1985); 242-57; Michele Feo, 'Politicità del Petrarca', Quaderni Petrarcheschi 9-10 (1992-93), 115-28; Giuseppe Mazzotta, The Worlds of Petrarch (Durham NC, 1993), esp. 102-28 and 181-92; István Bejeczy, 'The State as a Work of Art: Petrarch and his Speculum principis (sen. XIV, 1)', History of Political Thought 15·3 (1994), 313-21; Giovanni Ponte, 'I consigli politici del Petrarca a Francesco da Carrara (Sen. XIV, 1)', in Petrarca e la cultura 
political projects, at least in the short run, ended in failure, one could add the charge of ineffectiveness to those more frequently heard, of inconsistency and a certain excess of moral flexibility. ${ }^{2}$

There is one political Petrarch, however, who has drawn less attention from scholars than the rest, and that is the unpolitical Petrarch — at least if we follow the marxisant view that refusal to take part in politics is itself a kind of politics. To be sure, even this Petrarch has found critics among posterity: it was the unpolitisch Petrarch, after all, who disappointed the great historian of Renaissance republicanism, Hans Baron, and furnished the most important example of the key distinction he made between 'politically quietist' Trecento literati and the engagé civic humanists of the Quattrocento: between the humanist movement before and after the putative 'crisis' of the early Italian Renaissance. ${ }^{3}$ Criticism is not necessarily analysis, however, and there is much about the unpolitical Petrarch that still merits study and discussion, especially in an age such as ours, where admirable examples of political engagement are hard to come by, and alternatives to political life eagerly canvassed. Furthermore, in this case too Petrarch has left us a preemptive apologia for withdrawal from the active life in his treatise De vita solitaria, written and rewritten and rewritten again between 1346 and $1372 .{ }^{4}$ Though justifying his withdrawal from the active life is an intermittent concern throughout the work, I would like to focus in this essay on one

europea, ed. L. Rotondi Secchi Tarugi (Milan, 1997), 121-127; Ugo Dotti, Petrarca civile (Rome, 2001); Davide Bigalli, 'Petrarca: Dal sentimento alla dottrina politica', in Motivi e forme delle Familiari di Francesco Petrarca: Gargano del Garda, 2-5 ottobre 2002, ed. Claudia Berra (Milan, 2003), 99-118; Petrarca politico: Atti del convegno (Roma-Arezzo, 19-20 marzo 2004) (Rome, 2006); Giacomo Ferraú, Petrarca, la politica, la storia (Messina, 2006); Peter Stacey, Roman Monarchy and the Renaissance Prince (Cambridge, 2007), esp. chapters 3 and 4; István Dávid Lázar et al., 'Petrarca e la tirannide', in Acta conventus Neo-Latini Upsaliensis: Proceedings of the Fourteenth International Congress of Neo-Latin Studies (Uppsala 2009), 2:605-11; Albert R. Ascoli, 'Petrarch's Private Politics', in A Local Habitation and a Name: Imagining Histories in the Italian Renaissance (New York, 2011), 118-58.

2 I respond to these criticisms in a forthcoming article, 'Virtue Politics and the Political Thought of Petrarch'.

3 The most mature statement of Baron's views on Petrarch are found in his In Search of Florentine Civic Humanism: Essays on the Transition from Medieval to Modern Thought, 2 vols (Princeton, 1988); for an overview of Baron's interpretation of the early Renaissance and its reception, see my 'The Baron Thesis after Forty Years: Some Recent Studies on Leonardo Bruni', Journal of the History of Ideas, 56 (1995), 309-338; for the context of Baron's disdain for the unpolitisch Mensch, see Kay Schiller, Gelehrte Gegenwelten: Über humanistische Leitbilder im 20. Jahrhundert (Frankfurt am Main, 2000), 99-173.

4 See Ugo Dotti, Vita di Petrarca (Bari, 2004), 140-41; Petrarch, De vita solitaria, liber 1: kritische Textausgabe und ideengeschichtlicher Kommentar, ed. K. A. E. Enenkel (Leiden, 1990), 8, was 
passage in particular, found in Book Two (2.9.19-22)..$^{5}$ The passage stands out in the work as kind of confession of Petrarch's deepest convictions regarding the autonomy of the individual in the face of what present themselves as social and political obligations. It is also of considerable historical interest, as it throws light from a rather different angle on how he strove to reconcile his aims as a humanist reformer with his forma mentis as a believing Christian. Petrarch in effect sets up a dialogue between the Augustine of the City of God and Seneca's De otio in order to resolve the tension between his hopes of reforming the political elite of his day and his desire to remain unspotted from the world. What comes out of this confrontation is neither Augustinian nor Senecan, but Petrarchan, which is to say an attitude towards the self and its obligations that belongs more to the modern than to the ancient world.

A few words first about the project of the De vita solitaria (hereafter DVS), a far more radical one in the context of its time than is commonly appreciated. ${ }^{6}$ The work was begun in the Lenten season of 1346 , stimulated by a season of literary retirement Petrarch had enjoyed with his friend Philippe de Cabassoles (1305-1372). Philippe was a prominent papal diplomat from a noble family who in 1334 was appointed bishop of Cavaillon, thus becoming Petrarch's spiritual and feudal lord when the latter acquired a country house in Vaucluse in 1337, a short walk from Philippe's castle. The two became intimate friends and exchanged many letters preserved in Petrarch's various letter collections. As was his habit, Petrarch continued to add to and revise the DVs long after 1346; and

the first to find evidence of revisions as late as 1372. Ernest Hatch Wilkins, Life of Petrarch (Chicago, 1961), noted additions in 1362 (p. 182) and 1371 (p. 232).

5 In what follows I shall be citing Petrarch, De vita solitaria. La vie solitaire, 1346-66: Édition bilingue latin-français, ed. Christophe Carraud (Grenoble, 1999), which is based on Enenkel (see previous note) for Book I and the edition of Guido Martellotti for Book II, with minor changes. Martellotti's edition first appeared in Francesco Petrarca: Prose, ed. G. Martellotti et al. (Milan-Naples, 1955), 286-591, with an Italian translation, and was reprinted in De vita solitaria, ed. Guido Martellotti, with an Italian translation by Antonietta Bufano (Turin, 1977). There is a reasonably accurate English translation in The Life of Solitude by Francis Petrarch, tr. and ed. Jacob Zeitlin (Urbana, IL, 1924). I will cite both of the common reference systems, the first based on Petrarch's own subdivisions into books and chapters (with the paragraph numbers added by Carraud), and, following an 'equals' sign, a second created by the editors of the 1551 Basel edition, followed by Zeitlin and the older literature. I follow the Zeitlin translation, with modifications where necessary.

6 For the older literature on the DVS see Enenkel, De vita solitaria, 635-54; for more recent work see Armando Maggi, '“You will be my solitude”: Solitude as Prophecy (De vita solitaria)', in Petrarch: A Critical Guide to the Complete Works, ed. Victoria Kirkham and Armando Maggi (Chicago, 2009), 179-95 (notes on 409-14). 
though it was eventually declared finished in two books and sent to Philippe with a formal dedication in 1366 , Petrarch continued to fiddle with it down to 1372. Contemporary evidence shows that the treatise was used as a devotional work by its early readers, which cannot have been quite Petrarch's intention. ${ }^{7}$ In its wider historical context it might be regarded as an example of plague literature, as a work that carries the mental scars of the Black Death of 1347-49. In the peroration ending Book One (1.6.6) Petrarch even compares flight to the solitary life from the moral contagion of cities with flight from the plague, which most people at the time regarded as the only effective prophylactic against the disease.

The work developed in tandem with another work on the retired life, De otio religioso, begun during Lent in 1347, a year after the inception of the DVS. It too was continually revised, at least until 1357 , and possibly later. ${ }^{8}$ This second work was dedicated to the Carthusian monastic community at Montrieux, about 150 kilometers southeast of Vaucluse, where Petrarch's brother Gherardo was a monk. De otio religioso is a treatise that discusses religious retirement and the nature of monastic contemplation, a way of life described as the highest form of human life, the life closest to that of the angels (1.1). It is the life led by his brother Gherardo, whom Petrarch acknowledges to have taken a road through life higher than his own. ${ }^{9}$ Though in this work, as ever, Petrarch introduces a fresh personal perspective inspired by his classical reading, it remains fundamentally a traditional work of monastic meditation, rooted in the theology of the Church Fathers. The monastic life Petrarch celebrates in it was of course a well-established form of life in his day, lived in thousands of monasteries across Europe. As a form of life it hardly required justification in a Christian world, at least in the fourteenth century.

This is not the case with the DVS. In this work Petrarch introduces Christian civilization to a fundamentally new form of life, a form of life he has discovered

7 See Wilkins, Life of Petrarch, 204, 208.

8 On the date, see Giulio Goletti's remarks in his edition of De otio religioso (Florence, 2006), 7. However, in 1.2.62 (ibid., 30) Petrarch refers to the DVS 'quam nuper edidi'; its publication is usually dated to 1366 . On the relationship between the De otio religioso and the DVS see also the remarks of Ronald Witt in Petrarch on Religious Leisure, tr. Susan S. Schearer, intr. Ronald G. Witt (New York, 2002), vii-xxv. Yet in Fam. 19.3.20, dated to 25 February 1355, reporting to his friend Laelius a conversation with the Emperor Charles IV, Petrarch also claimed to Charles to have 'recently published' (nuper ediderim) the DVS.

9 The confession is made allegorically in the famous letter On the Ascent of Mt Ventoux (Epistulae Familiares 4.1, hereafter Fam., cited from the edition of Vittorio Rossi and Umberto Bosco (Le familiari, 4 vols [Florence, 1933-42]). The superiority of Gherardo's way of life is also a frequent theme in their correspondence, for example in Fam. 10.3.1-4 and 10.5.1-3. 
for himself: the life of otium litteratum or literary retirement. ${ }^{10} \mathrm{He}$ does his best to conceal its novelty by citing precedents for what he calls the life of the solitarius going back to Adam and the patriarchs, and including the Hebrew prophets, Church Fathers, popes, classical philosophers, poets, orators, Roman generals and emperors, and even 'men outside the Christian religion', such as the 'gymnosophists', Hindus and Druids. His point is to show that the impulse to withdraw from normal social interactions is universal, both historically and geographically. To show the universality of the impulse behind the solitary life was a necessary premise for someone whose aim was to defend it as a way of living: if the desire for such a life can be shown to be universal, it may be assumed to be natural, and therefore something intended by the Creator. At the same time, true examples of the solitary life are rare. Only morally serious, pious men devoted to literature can live such a life. 'It is not given to all men to excel by holiness of life or by literary achievement or by noble use of leisure to earn the love and acknowledgement of posterity' (1.5.4). Without literature, the solitary life is sheer boredom and misery; ${ }^{11}$ without good morals it can easily become depraved, like the emperor Tiberius' life at Capri (1.5.4). Some women have been solitaries, but they cannot be part of the solitary life of a man as Petrarch envisages it (2.3.3). Solitary men are typically those who have a spiritual and even physical disgust for the crowd, the vulgus, which necessarily embraces the vast majority of mankind. To consort with crowds in city life is to endanger one's soul. Petrarch describes vividly his own disgust with the sights and smells and behavior of common men, fearing that among such unlovely specimens of humankind he will 'unlearn humanity' (humanitatem inter homines dediscere, 1.4.9). ${ }^{12}$

What is most radical about the solitary form of life as Petrarch envisages it is its non-monastic character. It is intended for mature men who enter into it voluntarily, without taking vows. These men might be secular clergy living on sinecures or laymen of sufficient means, but they would not be 'religious' in the canonical sense, i.e. members of monastic orders who had taken formal vows of poverty, chastity, and obedience. They cannot be married, too young or

10 The model of life was not absolutely new because such ideals had existed in the ancient Greek world, as Petrarch may well have known from his Roman sources: see Eric Brown, 'False Idles: The Politics of the Quiet Life', in A Companion to Greek and Roman Political Thought, ed. Ryan Balot (Chichester, West Sussex, 2009), 485-500.

11 Petrarch echoes De tranquillitate animae 2.9-10, one of his favourite works by Seneca, and a constant presence in the DVS.

12 The phrase echoes Seneca in the Moral Epistles 7.3, who states that he comes home from popular spectacles 'inhumanior, quia inter homines fui.' 
too old, courtiers, merchants or artisans, office-holders in towns or clerics too involved with careers in the Church hierarchy. ${ }^{13}$ For Petrarch's solitaries there are no vows of silence (hardly imaginable for so voluble a man as Petrarch) and no rules about confinement within walls; Petrarch celebrates the wanderings of solitary men in the countryside, over rivers, meadows and mountains; his solitarii are rustic gyrovagues. Solitary men should live outside cities, but a liminal situation at the edge of cities, within easy walk of the countryside, is acceptable. That is how Petrarch lived during his eight years in Milan (1353-61), at what was then the edge of the city, near the basilica of Sant'Ambrogio, and during his various extended visits to Parma, although at other times he preferred to be somewhat more removed from city life, as at Vaucluse ( $35 \mathrm{~km}$ from Avignon) or Arquà ( $25 \mathrm{~km}$ from Padua).

The life lived by solitary men in Petrarch's conception is a life devoted to the study of literature and philosophy, Christian and non-Christian. It is explicitly contrasted with the mercenary studies of the medieval university, which Petrarch had experienced in Bologna as a young law student but rejected with disgust. 'I saw Bologna but didn't take to it' (Bononiam vidi et ... non adhesi). ${ }^{14}$ Anticipating themes of his later invective De sui ipsius et multorum ignorantia $(1367 / 71)$ Petrarch lays out in the $D V S$ a model of moral and intellectual self-cultivation that rejects the ethos of scholasticism. The latter for him represented a corrupt form of education, mere pre-professional training, oriented to power and money-making and transmitting expertise without concern for moral character. Scholasticism focuses on problem-solving in particular contexts; it is designed to train medical doctors or lawyers, future decision-makers in lay governments and in the Church. Petrarch's otium litterarium by contrast-revealing its Stoic inspiration-is designed to instil wisdom and virtue. It broadens the mind so that it adopts a universal perspective, the perspective of all of time and space. By ranging through past times and around the globe the solitarius is drawn out of the moment; he suppresses consciousness of those who work evil in the present by meditating on the fine deeds of great men in other times and places. By exchanging the company of the vulgar and the ugliness of the city for the company of the mighty dead and the beauties of nature, the soul is uplifted and purified. It enjoys an intimacy with God impossible in

13 Fam. 8.4 (discussed further below). Fam. 19.3.20, a letter to his friend Laelius about an offer from Charles IV to join his court, explains why the solitary life and the life of a courtier are also mutually exclusive.

14 Fam. 4.16. Petrarch attacks the moral vacuity of scholasticism in the DVs at Praef. 9-10, ed. Carraud, $3^{2-36}$. A more generalized attack on the learning of his day as morally and religiously defective is found in Fam. 10.5. 
the city. And a true literary life is really only possible for those who have withdrawn from the active life (1.4.10): 'Exemption from life's duties is the source of arts and letters' (vacatio litterarum atque artium fons est). The solitary and his friends, by reading, writing, and quiet discussion, help preserve the collective memory of humanity and the work of the great authors to whom it owed so much (traditio). By honouring in our work the discoverers of literature and the noble arts, Petrarch says, we are 'carving statues of illustrious men more enduring than brass or marble'. Our writings

pay to posterity the debt we cannot pay to the dead for the gift of their writings. [In this way we do not] remain altogether ungrateful to the dead but make their names more recognized if they are little known, restore them if they have been forgotten, dig them out if they have been buried in the ruins of time and hand them down to our grandchildren as objects of veneration, carry them in our hearts and as something sweet in our mouths, and finally, by cherishing, remembering and celebrating their fame in every way, pay them the homage that is due to their genius even though it may not be commensurate with their greatness (1.4.9). ${ }^{15}$

The self-cultivation of men in literary retirement is also non-hierarchical; Petrarch rejects the idea that one can only learn, or best learn, from a master (1.5.1). That is for schoolboys, not adults. Adult solitaries learn from each other on a basis of equality. Titles to learning such as doctorates do not guarantee real learning, as Petrarch demonstrates with a certain zest in two letters attacking his former teacher, Giovanni d'Andrea, the famous Bolognese jurist, for his pretense of knowing the classics. ${ }^{16}$ The life of the solitary man is also supremely free: free from the cares of the active life, from family cares, from the demands of social superiors (vacatio). In the country, by oneself, there can be no pressures for conformity (which Petrarch calls imitatio) in morals or in mores, in dress or in manners. There one needs only modest means to support a simple life; one can be authentically oneself, integer vitae scelerisque purus. Living unspotted from the world, warding off contamination from the profanum vulgus, unencumbered by the cares of this life, it is easier to prepare one's soul for the next.

\footnotetext{
15 Translation adapted from Zeitlin, 151.

16 Fam. 4.15-16 (the letters may be dated to 1442 ).
} 
Though the solitarius spends most of his time alone, in study and writing, it is of the essence of the solitary life that he enjoy close friendships. ${ }^{17}$ The solitary should fly from crowds, not friends (turbas, non amicos fugiendos dico); his life is one of solitude, not inhumanity (immanitas). $1{ }^{18}$ 'If I had the choice of doing without the one or the other, I should prefer to be deprived of solitude rather than of my friend' (1.5.4). Indeed, Petrarch's conception of the solitary life has a communal aspect: it is a virtual fellowship of learned men, bound by shared moral and spiritual values, sustained by moments of vivid personal contact but maintained also via a constant exchange of letters, books, and dedications - what a later age would call the commercium litterarum (a phrase Petrarch would surely have detested). The solitary and his friends, moreover, see themselves as belonging to a virtual society of philosophers and literary men, extended across time and space, sharing a common devotion to truth and goodness, a common culture. From this point of view Petrarch's two great epistolaries, the Familiares in twenty-four books and the Seniles in seventeen, provide a collective portrait of the fellowship of men who shared his life of literary solitude.

A group of these letters in Book Eight of the Familiares (8.2-5), written from Parma in May 1349, shows us that the ideal of living a solitary life with a few close friends was not a mere dream. After the Black Death had taken the life of his beloved patron, Cardinal Giovanni Colonna, Petrarch acquired sufficient means - thanks to another patron, Azzo da Correggio, the ruler of Parma-to propose forming a community of solitaries (if the expression may be allowed) that would live in the house he had purchased in 1344 on the outskirts of Parma. ${ }^{19}$ The community would consist of four former members of the cardinal's household: Luca Cristiani (Petrarch's 'Olympius', a cleric in minor orders, holder of a modest benefice in Piacenza), the Florentine humanist Mainardo Accursio (a descendent of the famous jurist), Ludwig van Kempen (Petrarch's 'Socrates', a well-known musician and musical theorist) and Petrarch himself. They would live a frugal life together as equals, without a lord, pooling resources, devoting themselves to the bonae artes, preparing

17 On Petrarch's wider views of friendship, see Claude Lafleur, Pétrarque et l'amitié (Paris, 2001). Cf. Seneca, De tranquillitate animae 7.3-6.

18 In humanist literature of the fifteenth century, immanitas is the lexical opposite of humanitas, often meaning something like 'cruelty' or 'barbarism.'

19 Dotti, Vita, 94-95. Like Vaucluse, the house permitted easy escape to the countryside, especially to Azzo's castle of Guardasone, $24 \mathrm{~km}$ to the south, from which Petrarch could wander through the wooded hills of Selvapiana; it was in Selvapiana that he took up anew his writing of the Africa, begun in Vaucluse. 
their souls in what remained of life for the life to come. Social equality was a necessity since inequality engendered pride and patterns of deference inimical to true friendship. Their former life as familiars of the cardinal, though he had been a good man without arrogance, had still been a kind of slavery:

$[\ldots]$ to be set under another, to obey another, to live on another man's support can seem part of a more honourable kind of enslavement, but these are surely not marks of freedom. Look now, freedom, hated as it may be, has fallen to our lot and we are our own men rather sooner than we desired [because of the Black Death]. And I think I know the attitudes of you all, or am I wrong? But perhaps I do not know all the obstacles, even though I think nothing of your nature was hidden from me. We are not lords of sea and earth as Aristotle says, ${ }^{20}$ nor do we have to be to win a blessed life. But we have a sufficiency for moderate spirits that accommodate themselves to nature. If that is enough for each, what do we expect will happen to us all when each in turn will give a hand to the other and whatever need befalls us will be supplied by another's resources? We will be overflowing, believe me, and should perhaps fear envy rather than scarcity.

So why are we waiting? Why are we kept apart by sea and mountains and rivers? Why doesn't a single house finally unite us, as unity of wills formerly united us, unless we are afraid of new and unfamiliar experiences and think it foolish to dismiss a hope that promises much and disregard a fortune that calls us to higher things? ${ }^{21}$

The solitary life, again, is not one that can or should be undertaken by everyone, and Petrarch nowhere is so bold as to rank it as the highest kind of human life. Its rarity makes it fine (on Aristotelian principles) but other kinds of life are also admirable. Petrarch's realistic attitude to the possibilities of life is brought out in the letters of advice he was sometimes called upon to write to young men who had read his works and as a result (no doubt to the alarm of their parents) had developed moral scruples about entering the active life. ${ }^{22}$ In one such

See Aristotle, Nicomachean Ethics 10.8.1179a.4-5. Petrarch alludes to a famous passage that makes his point very well, where Aristotle argues that only moderate resources are necessary for happiness in the contemplative life.

21 Fam. 8.4. The translation is from Francesco Petrarca: Selected Letters, tr. Elaine Fantham, 2 vols (Cambridge, MA, 2016), 1:495 (IV.11.23-25).

22 It should be noted that Petrarch, unlike his ancient Greek sources, includes among those practising the active life not only soldiers and statesmen but also lawyers and courtiers, temporal and spiritual lords and their superior servants. See DVS 1.2.4-9. 
case, writing perhaps around 1340 to a young man called Marco Portinario of Genoa, torn between monastic life and the life of politics, Petrarch warns the young man of the dangers to his soul inherent in a life seeking political power. But he does not counsel the 'higher' life of monasticism, because wise counsel needs to take account of circumstances and the bent of the individual as well as any fixed hierarchy of values. Repeating a theme of the $D v s$, Petrarch advises the young man that many great men in the past have begun as solitaries and later entered the active life (like Pope Sylvester I) or have begun in the active life and ended up, after the storms of life, in the safe harbor of solitude (like Pope Celestine I). In any case the active life of serving one's country has divine approval; he should not fear that care for his fellow citizens disqualifies him for the saving grace of God. Sounding for all the world like a civic humanist of the Quattrocento, Petrarch tells him he will not have been born in vain if he should choose to assist his fatherland with his labor and counsel,

especially in these times when it needs you so badly and, as Plato indicates, rightfully demands a part of your birthright for itself. Heavenly is that saying of my [Scipio] Africanus in Cicero's work [De republica 6.13]: 'For all those who have preserved, assisted, and supported their fatherland, there is certainly a definite place in heaven where the blessed experience joy eternally.' Well known is also what follows: 'There is nothing that may be done on this earth that is more acceptable to that supreme God who rules over all this world than the assemblies and meetings of men united by law and forming what are known as states.'23

A decade or so later the same man, no longer young, wrote again to Petrarch to share his misgivings about the moral effects of studying law. Petrarch wrote back, warning him of the evils to which a life in the law would expose him, especially in corrupt modern circumstances. Yet given the serious commitment Marco had already made to his legal education, Petrarch in the end urged him to persevere in the life he had chosen, supplying him with a panoramic history

23 Fam. 3.12.6. The translation is from Francesco Petrarch: Letters on Familiar Matters, tr. Aldo S. Bernardo, 3 vols (New York, 2005), 1:146. The passage from Cicero's De republica (preserved in Macrobius' commentary on the Somnium Scipionis) was the most famous passage cited in support of civic religion in the Quattrocento. Petrarch cites it again in his famous 'mirror of princes' directed to Francesco da Carrara, included among the Res seniles (hereafter Sen.) 14.1.28 (= V.6.28 Fantham). 
of the law in antiquity in order to inspire him to embrace higher moral standards in his jurisprudence than were being taught in modern universities. ${ }^{24}$

In short, Petrarch in the DVS was not trying to undermine accepted forms of life as such; his ugly pictures of moral corruption in contemporary cities were not meant to imply that the active life could never be lived with praise and without endangering the soul. Clearly it could, given the right times and the right circumstances. Petrarch's concern was to establish the legitimacy of his own, novel form of life- a contemplative life for laymen and for secular clergy in minor orders who did not have the care of souls-and to argue that, for those in his situation, such a life is morally preferable to other recognized forms of life in Christian society. He realizes, however, that the solitary life requires defense against the accepted norms of sociability in his time; he has indeed heard 'clamoring' and 'mutterings' from hostile critics who sought to invalidate the premises upon which his notion of the solitary life rested. This is where Petrarch is compelled to dip a toe into the unfamiliar waters of political theory.

In a passage near the end of Book Two (2.10.7) he addresses three authorities whose conceptions of the ethics of sociability appear to challenge the moral worth of the solitary life. The first is Aristotle and his definition of man as a political animal who completes his nature and acquires virtue by ruling other men, either permanently or (in popular regimes) by ruling and being ruled in turn. In a famous passage, Aristotle declared that someone who tried to flourish outside the polis would be not really human: he would be either a beast or a god..$^{25}$ Petrarch's response is simply to translate Aristotle's definition of

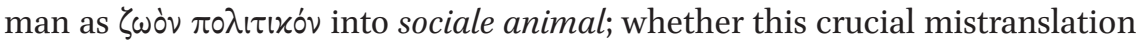
is intentional or not is difficult to say. ${ }^{26}$ In any case the mistake, if that is what it is, allows Petrarch to claim that his solitary life comes under the definition of a society, since it includes friends and serves humanity. Much earlier, in Book One (1.5.4), he had upended the Aristotelian association of full humanity with city life using one of his typical rhetorical paradoxes: it is urban dwellers who

24 Fam. 20.4 (= III.14 Fantham). Petrarch's advice to Marco Portinario tracks the advice given by Seneca to the non-philosophical man who is already embarked on public life in $D e$ tranquillitate animae 2.9-3.1.

25 Politics 1.2.1253a.

26 Ed. Carraud, 382: 'Deinde Aristotelicum illud obiciunt, ubi ait, vel quod naturaliter sociale animal est homo, vel quod, qui aliis non comunicat, aut bestia est aut deus.' The slippage from animal politicum to sociale was a common one in medieval political literature, going back to Thomas Aquinas (e.g. De regimine 1.1.3). See J. M. Blythe, 'Civic Humanism and Medieval Political Thought', in Renaissance Civic Humanism: Reappraisals and Reflections, ed. J. Hankins (Cambridge, 2000), 59-60. 
are bestial and solitaries who are godlike, or at least angelic. Thus he urges the solitary man to live in such a way that those who visit him

should have occasion to marvel that humanity, which is exiled from the cities, inhabits the wilderness, and that while he has found bears and lions in populous places, in solitude he has discovered angelic man.

As we have seen, Petrarch has already deployed the Stoic-Christian concept of spiritual equality to show the superiority of the solitary life to the life of ordinary men, most of whom must live in dependence on others. Implicitly he opposes Aristotle's view in the Politics, that to have one's human potentiality fully realized, one must command not only one's own soul but other men. Aristotle argues that to fully develop prudence and other virtues, one has to exercise one's virtue within the wider arena of the polis. ${ }^{27}$ His position reflects the perspective of a political elite, but Petrarch, the former retainer of a prelate, takes the view of the sottoposti, for whom social hierarchy, even under a virtuous superior, inevitably imposes a kind of slavery.

In the peroration of Book One (1.6.6) Petrarch goes further and claims that the solitary's struggle to master himself, in terms of its difficulty, its hazards, and its ultimate dignity, is a struggle equal to or greater than the corresponding struggle of a governor or a military commander to rule those placed under him:

In respect of numbers I admit their problem may be greater, for they are entrusted with large populations and vast armies whereas we have but the care of a single soul. But as far as risks are concerned, I deny that there is any difference.... We too have to expel vice from our borders, put our lusts to flight, restrain our illicit propensities, chastise our wantonness, and elevate our mind towards higher objects.... Let some govern a popular city [urbem populi] and others rule the army. Our city is that of our mind, our army that of our thoughts.... We too are commanders of our own affairs and similar risks call for similar precautions. Why do I say similar? Both our risk and our reward [i.e., eternal life] is greater.

Petrarch goes on to argue that no ruler or commander - the highest representatives of the active life according to the ancients - nor any system of law ever successfully mastered the untameable vices of the many, but the solitary has good hope of winning the battle for virtue in his own life against the passions.

27 Pol. 3.4; see Malcolm Schofield, Saving the City: Philosopher-Kings and Other Classical Paradigms (London, 1999), 103. 
That alone makes his life superior to the statesman's. In effect he claims that what counts in developing the virtues is not the larger arena of the city, but success in actually acquiring virtue; this seems to be an original argument (dare one say it), and one not unworthy of consideration within an Aristotelian theoretical framework. Aristotle's contention that the exercise of mastery over men is necessary to the finest form of the active life is thus internalized, transferred to the sphere of the soul. The solitary does not need politics to acquire the active virtues; indeed politics, messing about with the recalcitrant multitude, is a positive hindrance to achieving mastery over oneself, the highest aim of this life, fitting us for the next. Since the solitarius is able to acquire the active as well as the contemplative virtues, his is a complete way of life in itself, not epiphenomenonal to civic life, as is the contemplative life in Aristotle.

The second authority Petrarch needs to answer is Cicero. Critics of the solitary life 'mutter against me' Cicero's claim (in De officiis 1.158) that men are naturally sociable, and would associate together from inclination even if necessity did not make them form communities. Cicero's argument runs like this: even if people could have all their necessities supplied without social cooperation, they would still seek social intercourse to complete their happiness. In response, Petrarch simply grants that this is so, which is why he insists that the solitarius must cultivate true friendship. He admits that the solitarius cannot really do without the city - the symbiotic relationship between city and wilderness is a theme that runs throughout the DVS. But he insists that someone following the solitary life must have the autonomy to choose when to interact with the city and when to avoid it. He has no categorical duty to participate in a corrupt community, even if it is one's patria, at all times and in all places.

This point leads to the third objection against the solitary life. For this objection no authority is given, though it presupposes an organic conception of the state similar to Aristotle's, where the community is naturally prior to the individual. ${ }^{28}$ To modern ears the argument that advocacy of the solitary life is a threat to the state has an almost Kantian ring:

28 E.g. Pol. 1.2, 1252a-b. Elsewhere, when describing in idealized terms the government of Francesco da Carrara in Padua (Sen. 14.1.26 = V.6.26 Fantham), he chooses to employ the organic metaphor of the body politic: 'So you must love your citizens like sons, or rather, so to speak, like the limbs of your body or parts of your soul, since the community is one body, and you are its head.' In general, however, Petrarch prefers familial metaphors to describe signorial rule. 
'What would happen', they say, 'if you could persuade all men in general of your design? Who then would live in the cities? Beware lest you speak against the interests of the respublica.'

As an aside, it may be pointed out that civic humanists of the fifteenth century sometimes expressed similar views regarding monastic institutions, charging that they harmed the state by placing their vast resources, resources needed for the state's defense and flourishing, beyond its reach. ${ }^{29}$ In any case Petrarch's response is simply that, even were he to preach such a message in the city (which he would not), it would have no chance of success. If the vulgar started to stream out from the city to the solitudes of nature in obedience to his urging, they would no longer be solitudes. (Think Lake Como on a Sunday in August.) But this is absurd. 'The mores of mankind as a whole are not like this; the vulgus does not lend ears so alert and wide open to gentlemanly counsel' (honestis consiliis). In general Petrarch rejects dogmatic forms of altruism; charity is a matter of personal choice that reflects one's circumstances, not a categorical imperative (DVS 1.3.4). Like Seneca he holds that love of mankind had to begin with love of the self. If one did not prioritize the good of one's own soul, one would never be able to enlarge one's sympathies towards others: towards family, friends, country, and ultimately towards the whole cosmos. Charity begins at home..$^{30}$

These challenges to Petrarch's conception of the solitary life, revealing though they are of an unpolitical man's attitude to politics, were relatively easy to answer. That is not the case with two other challenges presented in the long passage I promised to comment on at the beginning of this essay, which is given in full in the Appendix with an English translation. These were challenges that came not from external critics but from internal conflicts between his own deepest convictions.

29 For example Poggio Bracciolini's Contra hypocritas dialogus (1448), in Bracciolini, Opera Omnia, ed. Riccardo Fubini, 3 vols (Turin, 1966), 2:39-80.

30 For the sources of the proverb 'Charity begins at home', to which Petrarch alludes, see Carraud's note 149, 404. For the Stoic doctrine of oikeiosis, how the wise man following reason expands his sympathies from himself to his family, friends, country, and the cosmos, see Martha Nussbaum, 'Kant and Stoic Cosmopolitanism', The Journal of Political Philosophy 5.1 (1997), 1-25. The opposite of Petrarch's Stoic view would be represented by the recent work in the utilitarian tradition of Peter Singer, The Most Good You Can Do: How Effective Altruism is Changing Ideas about Living Ethically (New Haven, 2015), for whom ceteris paribus your mother has no greater claim on your charity than a baby in Bangladesh, and quite likely less. 
The passage in question comes at the end of a long digression in Book Two which must have been inserted some time after 1355 , since it refers to Charles IV's quick passage through Rome in April of 1355 to 'snatch his imperial crown' (rapto dyademate, 2.4.3). ${ }^{31}$ The passage begins with a discussion of Peter the Hermit (c. 1050-1115), the solitary whose preaching, according to Petrarch, was really responsible for inspiring the Crusades - not Pope Urban II's. Petrarch then discusses the history of Christendom: how in antiquity the faith had spread through the whole world, even passing beyond the borders of the Roman empire, but had afterwards shrunk under pressure from the Muslim ('Egyptian') conquests; how the Crusades, initially a success, had more recently failed owing the lack of commitment from cowardly, weak, and selfish Christian princes, among whom he includes the pope, the Holy Roman emperor, and the emperor of the Greeks in Byzantium. Blame for the relative collapse of Christendom since antiquity is thus placed squarely on the shoulders of the corrupt princes of Christendom. Given their failures, they have no right to despise the pagan heroes of ancient Rome. If Caesar were to return from the underworld today and acknowledge the name of Christ, 'as he surely would' (ut haud dubie faceret), he could easily subdue Egypt as he had done in the first century ВСЕ as a gift for Cleopatra; in gratitude for his salvation he would surely make the same gift now to Christ. Petrarch then loses himself in a fantasy that the ancient heroes of Rome might come back from the dead as baptized Christians:

Would they suffer the name of Christ to be held in contempt in the regions associated with their glory? ... If, wanting the light of true faith, they dared such great enterprises for an earthly country, what do you suppose they would have dared with Christ leading them to success?

That is what Christendom needs now: Christians with the virtue and zeal of the ancient Roman heroes. Such prodigies would certainly not behave like the princes of modern Christendom, who prefer to serve the interests of their own corrupt regimes rather than the interests of Christ and our one true homeland, the Heavenly Jerusalem.

This sets up the final passage in the digression, the passage which provides the focus (or pretext) of this essay. It is as though Petrarch realises almost too late that he has found himself praising pagan heroes of the active life while

31 Petrarch had urged him to take up permanent residence in Rome, thus reestablishing the empire as Roman, and was disgusted when Charles stood by his agreement with the pope to leave immediately after his coronation: see Fam. 19.12. 
supposedly defending the solitary life. This involves a certain amount of backtracking and qualification. Two voices in his head have started a dialogue. One is his humanist voice, the trumpet-voice that blares forth inspiring examples of noble conduct from classical antiquity with the aim of reforming Trecento Christendom. The stench of corruption coming from that world has led to a crisis of legitimacy; it is careening towards the bottom of its historical cycle; but it might begin to rise again if ancient pagan virtue and early Christian faith can somehow be recovered and combined by modern Christians. Petrarch's first, naively political project of civilizational renewal had suffered an appalling setback with the sudden collapse of Cola di Rienzo's movement, but hope for such a renewal or rebirth never entirely faded in later life, though it gradually mutated into something like a cultural movement. In personal terms Petrarch's humanist conscience exposed a fork in his own road: he could either continue in the solitary life, preserving and adding to the classical literary heritage for posterity, hoping for better times to come; or he could take another road, become a familiar and counselor of princes, with the temptations to wealth, status, and fame that involved, but also with the chance of effecting real moral change in the present. ${ }^{32}$

The other voice in his head is Augustine's, whose City of God he was meditating on as he wrote the passage under discussion. Augustine- the 'philosopher of Christ' to whom Petrarch credited his personal reformation ${ }^{33}$ - presented him with a tragic view of the Christian's duty towards the state that Petrarch simply could not accept. Augustine, writing after the Visigoths' sack of Rome in 410, believed the end times had come, and the world of time, the saeculum, was about to be rolled up into the scroll of eternity, making chances of political reform limited not to say short-sighted; a bad investment of time that might better be spent on one's soul. With his residual Neoplatonism Augustine thinks of the temporal world, the world of history, as nothing but an inferior copy of the heavenly Jerusalem, the City of God, the eschatological society that will come into being at the Second Coming. ${ }^{34}$ Owing to its inherent metaphysical inferiority, the temporal world of our experience never had a chance to achieve real virtue or true glory; ${ }^{35}$ the vaunted virtues of the old Romans were always vitiat-

32 Dotti, Vita del Petrarca, 277-78.

33 De otio religioso 2.7; for Augustine as 'philosopher of Christ', ibid. 2.5, and Fam. 17.1.11.

34 On Augustine's notion of the secular, see R. A. Markus, Christianity and the Secular (Notre Dame, IN, 2006).

35

The point often goes unrecognized by modern historians of political theory who fail to consider the metaphysical rationale behind Augustine's refusal of political action for the betterment of society; for example, in the otherwise illuminating article of Peter Burnell, 
ed by a false religion and by false motives: the love of glory rather than the love of God. Love of glory is an obstacle to spiritual progress; at best it can check the worst excesses of libido dominandi, but nothing more. Since 'an individual's true moral status consists in his inner disposition, ${ }^{36}$ not in the objective results of his acts (as Petrarch too believed), the value of the old Roman heroes as models for Christians was limited (which Petrarch did not believe). The Roman empire, even at the apogee of its power, was always violent and corrupt. At best it provided peace and a semblance of order. It could not take credit even for its conquests; its power to rule had been given it by Divine Providence.

But herein lies the tragedy. Despite the wickedness of the Roman empire, the Christian cannot and should not refuse to serve in its offices if called upon to do so. The state provides peace and 'a shadow of justice', and the benefits Christians derive from these goods generate a duty to participate in the state. 'Human society constrains [the wise Christian] and sets him to perform his plain duty; to desert human society he considers unspeakable wickedness (nefas). ${ }^{37}$ Participation in rule unavoidably means participation in the administration of justice. However, such are the conditions of earthly justice that anyone who participates in government will inevitably commit some injustices owing to our inability to see into the hearts of others. Augustine gives as an example the Roman practice of obtaining evidence under torture: how is one to know whether to condemn someone based on evidence obtained by such means? One cannot. Doing injustice is unavoidably part of civil life, and the fact that the Roman empire was now officially Christian had not changed that fact. One can hope for and expect some slight improvement in political justice from the participation of Christians in it, but the number of true Christians is too small, and comes too late in time, to alter the fundamental reality: our civic obligations sometimes force us to do evil, albeit unwittingly and unwillingly. We have to wage just wars precisely because they are just; if they were not we

'The Problem of Service to Unjust Regimes in Augustine's City of God', in The City of God: A Collection of Critical Essays, ed. Dorothy F. Donnelly (New York, 1995), 37-49. For an antidote see Andrea Nightingale, Once out of Nature: Augustine on Time and the Body (Chicago, 2011), esp. chapter 1. It would be absurd to pretend that Petrarch had a metaphysics, of time or anything else, but prolonged, receptive reading of Cicero and Seneca gave him something like the forma mentis of a Stoic and thus a very different, more hopeful attitude to the world of time and change.

36 Gerard O'Daly, Augustine's City of God: A Reader's Guide (Oxford, 1999), 79, on which I rely for the generalizations in this paragraph.

37 De civitate Dei 19.6: 'In his tenebris vitae socialis sedebit iudex ille sapiens an non audebit? Sedebit plane. Constringit enim eum et ad hoc officium pertrahit humana societas, quam deserere nefas ducit.' 
would be relieved of that duty, but the injustice of the opposing side lays on the wise man the duty of waging war, with the inevitable evils that follow (19.7). We cannot in this life truly remain unspotted from the world. We must not abandon our duty, even to an evil world. ${ }^{38}$

The relevant passage in DVS shows Petrarch negotiating between these two voices in his head. In the end he finds a way to cut through the fearful rigour of Augustine's logic. Petrarch simply denies that one has an unconditional duty to participate in the active life of politics and war. ${ }^{39}$ Only a state ruled by justice and fair laws can command one's allegiance. Furthermore, he refuses to downgrade the virtue of the old Roman heroes in Augustine's way: by impugning the purity of their motives. The old Roman respublica (which for Petrarch includes the period from the early kings down to the early empire $)^{40}$ was a good state, 'as Sallust and Livy and many others have written', and worth fighting for, and the men who did so deserved the praise they won. Petrarch agrees with Cicero that the old Roman commonwealth was good, citing, via Augustine (Civ. Dei 19.21), a long passage from Cicero's De republica and another directly from the De officiis (2.26). Even if the Romans were extremely violent and coercive in imposing peace (as Augustine had charged), 'it was in the interests of those who were coerced to be coerced, however distasteful that might be, and in the interest of the world that it have a single head of affairs [i.e., Rome], provided it were the best and finest head'. Or rather (he corrects himself), he might agree with Cicero, he is ready to grant the Romans' supreme justice and goodwill towards mankind, but (as a Christian) he has to register one strong caveat. They had to be faulted - and Petrarch admits it was a great fault — for refusing their obedience to the true God and for worshipping His enemies, the pagan gods, instead. He then refers the reader to Augustine's detailed (curiose) discussion of the passage from Cicero. ${ }^{41}$

38 Burnell, 'Service to Unjust Regimes', 40: 'One must do one or the other, for of the three logical possibilities - cooperating, opposing or abstaining [from participation in unjust regimes] —abstaining is not an option: while not necessarily refusing all excuses, Augustine has refused the permanent ubiquity of social injustice as an excuse for permanent retreat from public life.'

39 For another example of Petrarch expressing disagreement with Augustine, see Fam. 15.9.5-14 (= VI.7.5 ${ }^{-14}$ Fantham), where, on a closely related issue, Petrarch vigorously rejects Augustine's description of Rome as the 'new Babylon' (a term he liked to reserve for Avignon).

40 See my forthcoming article, 'The Pure Radiance of the Past: Petrarch on the Roman Empire.'

41 Martellotti and Carraud refer us to Civ. Dei 19.21, where Augustine specifically denies that there ever was a Roman republic answering to the description of Rome in the Somnium 
This was a striking position to take. The upshot of all Petrarch's tortured syntax was that the Romans had a good commonwealth but a bad religion. The good commonwealth, the great Roman heroes like Scipio Africanus, can and should be a model for moderns; but not the bad religion. Petrarch's silence on the issue of what had motivated the Romans in their quest for glory-an issue fundamental for Augustine-is noteworthy. In any case, the ancient Romans were right to serve their commonwealth because it was just; and we are right to withhold service to our corrupt modern commonwealths because they lack justice; no political obligation exists in a society where there is no justice. If things were to change, one's obligations would change as well. Petrarch's high appraisal of the ancient Roman republic and its moral foundations leaves open-as Augustine does not - the possibility that modern Christian rulers might once again embrace classical virtue and wisdom. He leaves open, in other words, the possibility of a Renaissance.

Petrarch does not explain the source of this line of reasoning, but in fact, as all commentators have noted, it comes from Seneca's fragmentary treatise $D e$ otio. It is no doubt significant that Petrarch, for once, is silent about the source of his ideas; it would not do to follow a pagan philosopher in preference to 'the philosopher of Christ. ${ }^{42}$ For Petrarch goes on to argue (implicitly) against Augustine, echoing various passages in the Senecan text, that one need not fight for 'an unjust country with evil customs, such as nearly all the ones we see today'. If one were to shed one's blood for a corrupt patria one would in effect be trying to save its citizens from the justice of God, since (on Augustinian principles) defeat in battle is God's way of punishing wicked peoples. A man who fights for a corrupt country deserves no praise, no memorials; to indulge for a moment in the reductio ad Hitlerum, Nazis do not deserve our admiration, however selflessly they may have fought for the Fatherland. The only country that deserves our unconditional loyalty is the Heavenly Jerusalem, for whose sake there would be nothing it would not be right to dare or to do.

The echoes of Seneca are important since they come from a famous passage where the Roman philosopher discusses the very same issue, the morality of serving corrupt regimes. The Roman philosopher appeals to the principles of Stoic cosmopolitanism to find justifications, under some circumstances,

Scipionis. Augustine, however, is the source of Petrarch's idea that Roman rule was just even though it required at times unjust coercion to maintain order. of exceptions. 
for withdrawal from public life. ${ }^{43}$ There are times when one's native commonwealth (respublica) is in such a bad condition that a good man cannot be of service, and under these circumstances the usual Stoic view that men should serve their fellow men by entering public life has to be relaxed. In this case a life of private leisure and philosophical study can be defended. Such a life observes the higher Stoic principle that governs the duty of political participation, namely the good man's obligation to serve humanity and the good of the human race. A man who cultivates wisdom and the life of virtue in retirement (otium) is justified in that eo ipso he prepares himself to benefit others. He can do so, even when the state in which we were born is corrupt, or even when all states are corrupt, because Stoicism teaches us that as rational beings we belong to two commonwealths, that of our birth, and the greater commonwealth in which we are citizens together with all men and the gods. Moveover, nature has given us a natural desire for knowledge and contemplation, and 'to employ the fruits of our contemplation in the service of humanity by writing and teaching satisfies the wider requirement. ${ }^{\prime 4}$

We can see from this summary how Petrarch has used Seneca to correct Augustine, but as usual Petrarch digests his authors without being mastered by them - a procedure, by the way, he recommends in the sphere of literary imitation as well. ${ }^{45}$ Seneca licenses Petrarch's withdrawal from civic life, but as a deracinated literatus Petrarch feels no real commitment to any statecertainly not to his own poor, long-abandoned Florence-except perhaps to the Rome he saw reborn in his dreams. He certainly does not share Seneca's reluctance in the De tranquillitate (4.8-5.3) to abandon service even to bad states. But the great difference with Seneca, of course, is Petrarch's identification of the universal commonwealth of gods and men with the Heavenly Jerusalem. The difference is important. The Heavenly Jerusalem exists only in the future, in eternity, in saeculum saeculorum, and includes only Christians saved by the grace of God. No matter how cosmopolitan Petrarch may have been in his way of life, he was never a cosmopolitan in the sense that word was used in ancient Stoicism. For him Seneca's arguments lead to something more

43 See the discussion by Miriam Griffin, 'Seneca and Pliny', in The Cambridge History of Ancient Greek and Roman Political Thought (Cambridge, 2003), 532-58, at 555-58. Griffin remarks that the question of whether or not one should abstain from public life is a persistent theme in Seneca's writings. The De tranquillitate animae is highly relevant in this context; see esp. caps. 3-4.

44 Griffin, 'Seneca and Pliny', 556.

$45 \quad$ Fam. 22.2, to Boccaccio (= III.18 Fantham). 
like the 'negative' cosmopolitanism of the Cynics, a formula used to deny that the polis is the only possible focus of one's existence. ${ }^{46}$

Petrarch's divergence from Augustine, anguished though it clearly is, has significant implications. It is a necessary implication of what I have elsewhere called 'virtue politics' that states run by wicked men forfeit their legitimacy, their right to command our obedience and service. States that lack justiceeither because they lack fair laws or are ruled by evil men-are obeyed only from fear and prudence; we do not sacrifice ourselves for them for the sake of duty. The roots of natural sociability, based in gratitude, have withered away. The wickedness of rulers trumps the fundamental loyalty one owes to one's country, or ought to owe to it. In virtue politics, the obligations of political obedience are always conditional. Jesus' injunction to obey the civil authorities is downgraded to a mere counsel of prudence; it is not a categorical endorsement of the legitimacy of present powers or a licence for misrule. The structure of obligation is in effect the reverse of that common dilemma of modern utilitarian politics: can one use unjust means to achieve just ends? That sort of dilemma can arise from a Machiavellian calculus of ends and means, but is foreign to virtue politics, where ends and means are identical. In the tradition of virtue politics, acting unjustly to achieve justice is strictly speaking a self-defeating act. Justice is not mere adherence to positive law-legality—nor is it posterior to the acquisition or retention of political power. It is, precisely, acting justly.

In this respect Petrarch is a true representative of virtue politics. He sees no modern commonwealth that can command his loyalities and feels fully justified in removing himself from the Trecento equivalent of public life: life in the court of a prince or prelate, or life as an officeholder in a city-republic. His violent distaste for the politics of his time leads him to the radical conclusionradical in his late-medieval context - that he has no categorical duty to obey the powers that be, whether they claimed to be appointed of God or not. Political obligation has to be mediated by an autonomous personal judgment that a given commonwealth is just or unjust, worthy or not worthy of our obedience. Like the Stoics and later humanists, to be sure, Petrarch does not deny that we are born with fundamental, inescapable duties to others; like later humanists he loves to quote the line of Plato reported in Cicero's De officiis (1.22): 'We are not born for ourselves alone, but our friends and our country each claim a share in our origins.' Seneca added all humanity to that list of innate

46 See J. L. Moles, 'Cynic Cosmopolitanism', in The Cynics: The Cynic Movement in Antiquity and its Legacy, ed. R. Bracht Branham and M.-O. Goulet-Cazé (Berkeley, 1996), 105-20; and David Konstan, 'Cosmopolitan Traditions', in Companion to Greek and Roman Political Thought, ed. Balot, 473-84. 
duties. But we have the autonomy to decide which of those duties deserve to be the focus of our moral benevolence. ${ }^{47}$ Political obligation is a two-way street: governments can claim our obedience but they also have to earn it; obedience can licitly be refused. Petrarch has thus taken a step in the direction of the autonomous subject of modern politics, a subject who is free to enter into political contracts or to resist the authority of governments that do not reflect his own will. His ability to defend a degree of personal moral autonomy within the broader framework of the natural law tradition deserves more acknowledgement than it has found in histories of modern moral thought. ${ }^{48}$

Elsewhere I have shown that Petrarch systematically cast doubt on the modes of legitimation used by medieval governments to justify their rule. ${ }^{49} \mathrm{He}$ expressed scepticism about the papacy's right to translate the empire from the Roman people; he questioned the right of the Germans to exercise imperial power. He did not argue that the Donation of Constantine was a forgery but he doubted its legal validity. In general he dismissed legal titles to power in preference to an ancient, but in his day unfamiliar criterion of justice: the virtuous exercise of power. Only persons who have command of themselves, and therefore know how to impose kosmos, divine order, on the anarchy of human passions, are worthy of commanding others. The next century of humanism, from Salutati down to the time of Machiavelli, would undertake a great experiment to see if Italy, the ancient mother, could once again give birth to such extraordinary human beings.

47 In other words, Petrarch's idea of political autonomy is not fully individualistic, and in that respect does not easily map on to modern Kantian and utilitarian forms of autonomy. In general see Leslie Green, 'Legal Obligation and Authority', The Stanford Encyclopedia of Philosophy, at <http://plato.stanford.edu/archives/win2012/entries/legal-obligation/>.

48 According to the standard work on the origins of modern ideas of autonomy, J. B. Scheewind's The Invention of Autonomy: A History of Modern Moral Philosophy (Cambridge, 1998), modern ideas of autonomy depend on 'setting religion aside', and abandoning the framework of the natural law tradition, a process that for him only begins with Machiavelli.

49 See my forthcoming article, 'The Pure Radiance of the Past: Petrarch on the Roman Empire.' 


\section{Appendix}

\section{Petrarch on Political Obligations}

De vita solitaria II.ix.19-22

Text: Edited by Christophe Carraud in the volume cited in note 5 above, 284-29o. Some punctuation and paragraphing have been adjusted.

19. Non pro patria qualibet audenda sunt omnia, quanquam qui ausi sunt, multis ad celum laudibus afferantur. Laudatur ex nostris Brutus, laudatur Mutius, laudatur Curtius, laudantur Decii, Fabii, Cornelii, qui sanguinem suum pro patria effuderunt. Laudantur et exteri; similis enim virtus non dissimilem laudem meretur. Codrum ac Themistoclen Athene laudant, Lacedemon Leonidam, Epaminondam Thebe, Carthago Philenos fratres, alieque urbes cives alios.

20. De quibus omnibus si quid sentiam queris: celestis amanda respublica est, quam non tumultus tribunitii, non secessiones plebis, non senatus insolentia, non invidia simultatum, non bella civilia, non externa perturbant, pro qua quisquis sanguinem suum dedit, bonus civis et premii certus est. Non quod ideo temporalem hanc terrenamque patriam deserendam rear, pro qua, si res exigat, pugnare etiam iubemur, sed ita demum, si iustitia regitur et legibus equis vivit; qualem aliquo tempore fuisse rempublicam Romanorum Salustius ac Livius multique alii scripsere.

21. De quo in primis acriter copioseque disputat Cicero, in his libris quos De republica scripsit. Quibus facile consentirem, ut tunc, etiam dum toti orbi vim faceret et violentissima videretur, iusta esset, quod his ipsi, qui cogebantur, expediret cogi, et unum idque, nonnisi optimum et excellens, rerum caput esse mundo, licet gustu asperum, certe necessarium foret, nisi, quod dicam, huic sententie vehementer obstaret. Quod scilicet, etsi inter homines iustitiam servarent cuique ius suum tribuendo et illis romanis artibus a poeta descriptis pacis morem imponendo, parcendo subiectis et superbos debellando; quamvis, ut preclare ait Cicero idem alibi, 'imperium populi romani beneficiis teneretur, non iniuriis; bella aut pro sotiis aut de imperio gererentur; exitus bellorum essent aut mites aut necessarii; regum, populorum, nationum portus esset et refugium senatus; nostri autem magistratus imperatoresque ex hac una re maximam laudem capere studerent, si provincias, si sotios equitate et fide defendissent', essetque verissimum, quod 'illud patrocinium orbis terre verius quam imperium poterat nominari'; quamvis hec, inquam, si erga homines summa iustitia et innocentia Romanorum illius temporis acta consenserim, iniustos tamen in Deum fuisse non ambigitur, cui non leve aliquid sed se ipsos abstulerant fugitivorum more servorum sui furtum damno facientes, quodque gravissimum furti genus, cultum Illi debitum Eius hostibus exhibentes. Que nimirum iniustitia multo est maior, quam si vicino fundus 
avitus aut mancipium raperetur. 22. Qui locus ab Augustino in sue Celestis reipublice libris excussus curioseque tractatus est.

Quid vero, siquis nascendo patriam nactus iniustam malis moribus, quales fere nunc omnes vides? Num pro tali sanguinem fudisse laudabitur? Nichil minus. Quippe qui malis viris, improbis civibus impunitatem publicam facinorum propria morte quesierit, hunc tu michi laude dignum ac memoria? — quam<quam $>$ multis ob hanc causam contigisse quidem legimus. Hunc tu michi per gloriam vivere dixeris? Ego et vite prodigum et bis mortuum dicam, qui simul corpus atque animam, simul hanc vitam proiecerit et eternam. Contra autem, ne longius vager, pro celesti Ierusalem, pro patria illa perpetua, que beatum nobis spondet habitaculum, sine fine, sine labore, sine solicitudine, sine metu, sine ulla denique molestia, in qua nil turpe, nil impium, nil iniustum habitat, quid non vel audere vel aggredi iustum esset, siquid pietatis aut iustitie esset in nobis?

23. Iam vere ut Petrus a patria, sic ego longius ab incepto peregrinatus sum, hosque michi animos unius solitarii senis occursus dedit, ut orientale nostrum obprobrium occidentis principibus ac populis exprobrarem. Qua in re tam efficax utinam dextera mea sit quam illius lingua fuit! Quod frustra me optare certe scio; vereor magis ne importune nimium et audacter hec locutus videar inter illos, quibus libertas animi temeritas, et veritas furor, et admonitio omnis iniuria est. Utcunque res accepta erit, ego his verbis et digressione hac levatus gravi et molesto fasce querelarum, ad suscepte narrationis iter alacrior redeo.

\section{Translation $^{50}$}

19. Not for any country whatever are all things to be dared, although those who have died are exalted to the skies with much praise. Among the men who have shed blood for our country praise has been won by Brutus, Mutius, Curtius, the Decii, the Fabii, and the Cornelii. Foreigners are praised too, for a like virtue deserves like praise. Athens praises Codrus and Themistocles, Sparta Leonidas, Thebes Epaminondas, Carthage the brothers Philenus, and other cities praise other citizens.

20. If you ask my view about all this, it is the heavenly republic that is to be loved, which is not roiled by the tumults of tribunes, secessions of the plebs, the arrogance of the senate, envy and feuding, civil and foreign wars. Whoever gives his blood for the heavenly republic is a good citizen and sure of reward. Not that I think on that account that this temporal and earthly country should be forsaken; if circumstances demand it, we are bidden to fight for it too, but in the end only if it is ruled by justice and lives

$5^{\circ}$ The translation is mine, though some phrases have been borrowed from the version of Jacob Zeitlin cited in note 5 above, $250-252$. 
by fair laws - the sort of country that the Romans' republic was at one time, as Sallust and Livy and many others have written.

21. Cicero in his books On the Republic argues this point acutely and at great length. I might readily agree that, at that time, it was just even when it was imposing force on the whole world and appeared to be extremely violent, because it was in the interests of those who were coerced to be coerced, however distasteful that might be, and in the interest of the world that it have a single head of affairs, provided it were the best and finest head. Except that what I shall now say would represent a strong objection to that argument. Namely this: that although they may have preserved justice among men, rendered to each his due, imposed through those Roman arts of peace described by the poet a habit of peace, 'sparing the defeated and subduing the proud;'51 although, as the same Cicero elsewhere splendidly says, 'the empire of the Roman people may have been maintained [or, to use the archaic English subjunctive, 'were maintained'] through acts of service, not injustice, though its wars may have been waged on behalf of allies or for supremacy; though victory may have been accompanied by gentleness or only such force as necessity demanded; though the senate may have been a refuge and a harbor for kings, peoples, and nations; though our magistrates and generals may have sought to win the highest praise only for having defended our provinces and allies with fairness and loyalty;' and allowing it to be utterly true that 'their empire over the whole world could have more truthfully been described as a protectorate than as an empire'52 - although, I say, I might agree that the empire of the Romans of that time was conducted with the highest justice and good will towards mankind, still, there can be no doubt that they were unjust towards God, for they deprived Him of something not insignificant, namely of themselves, in the manner of fugitive slaves making theft of themselves from their master, and, what is the most serious form of theft, offering to His enemies [i.e., the pagan gods] the worship due to Him, which is doubtless a much greater injustice than if some ancestral estate or property were seized from a neighbor. 22. The passage [from Cicero] is examined and discussed in detail by Augustine in his books On the Heavenly Republic. ${ }^{53}$

But suppose someone happens to be born in an unjust country with evil customs, such as nearly all the ones we see today? Shall he be praised for shedding blood for such a country? Not at all! Are you really telling me that a man who sacrificed his life

$5^{1} \quad$ Vergil, Aeneid 6.852-3.

52 De officiis, 2.26. In the original text the verbs are in the indicative; Petrarch changes them to the imperfect subjunctive not to throw doubt on Cicero's statements but because the whole thought is rendered in a conditional form; such future-less-vivid constructions are a persistent stylistic tic of Petrarch's moral writing, symptomatic of his wider scepticism about absolutes in politics.

De civitate Dei 19.21 . 
to ensure that the deeds of wicked men and bad citizens not receive public punishment deserves praise and memorials? - although we read this has in fact happened in such cases to many. ${ }^{54}$ Are you telling me that this man lives on in glory? I say that the man was doubly prodigal, of both his life and his death, and has thrown away his body and his soul at the same time, both this life and eternal life. On the other hand, not to wander too far, if there is any piety or justice in us, what would it not be right to dare and do on behalf of the Heavenly Jerusalem, for that lasting country which assures us of a blessed dwelling-place without end, without toil, without anxiety, without fear, without any vexation, in which there dwells nothing disgraceful, nothing impious, nothing unjust?

23. Truly I have now journeyed as far from my beginning as Peter [the Hermit] did from his home. The encounter of a single solitary old man gave me the courage to rebuke the princes and peoples of the West with our reproach in relation to the East. [i.e. for its failure to protect Jerusalem from the 'Egyptians']. Would that my right hand [i.e. his writings] were as effective in this as was Peter's tongue! That this wish is vain I am not at all sure;55 my greater fear is lest I should be thought to have spoken with too much insistence and boldness by those who regard freedom of mind as recklessness, truth as madness, and every exhortation as an insult. ${ }^{56}$ But however the matter may be received, being now by these words and this digression eased of the heavy and distressing load of my grievances, I return to the path of the original narrative with greater alacrity.

54 The argument assumes that defeat of one's country is God's punishment for wickedness, or God's testing of the virtuous, an assumption found throughout Augustine's De civitate $D e i$. To the extent that one fights for the victory of a morally depraved country, one is fighting the judgment of God.

55 Is Petrarch expressing hope that his counsels will be heeded, and Christendom renewed?

$5^{6}$ Possibly an allusion to or echo of Seneca, De tranquillitate animae 6.2, where Seneca justifies withdrawal from public life in the case of persons excessively prone to freedom of speech who might bring harm upon themselves in the normal circumstances of court life. 